\title{
XIX. Of an attempt to make the maple sugar above an hundred years ago
}

\section{Dr. Thornton}

To cite this article: Dr. Thornton (1798) XIX. Of an attempt to make the maple sugar above an hundred years ago, Philosophical Magazine Series 1, 1:3, 322-323, DOI: $10.1080 / 14786449808676845$

To link to this article: http://dx.doi.org/10.1080/14786449808676845

曲 Published online: 04 Mar 2010.

Submit your article to this journal $₫$

Џll Article views: 2

Q View related articles $₫$ 


\section{$\left[\begin{array}{ll}322 & {[}\end{array}\right.$}

XIX. Of an Attempt to make the Maple Sugar above an bundred Years ago. Communicated by Dr. THORNTON, LeEturer on Medical Botany at Guy's Hoppital, \&ैc.

$\mathrm{I}_{\mathrm{T}}$

$T$ appears, by the following correfpondence between Dr. Robinfon and Mr. Ray, that the property of the American maple of yelding a faccharine juice was known above a century ago, and that attempts were even made to produce fugar from it :

\section{Dr. RoBINSON to Mr. RaY.}

" Dear Sir, London, Marcb 10, 1684 .

"I have enclofed you fome fugar of the firt boiling got from the juice of the wounded maple: Mr. Afhton, Secretary to the Royal Society, prefented it to me. 'Twas fent from Canada, where the natives prepare it from the faid juice ; eight pints yielding commonly a pound of fugar. The Indians have practifed it time out of mind; the French begin now to refine it, and to turn it to much advantage. If you have any of thefe trees by you, could you not make the trial, proceeding as with the fugar cane?"

$$
\begin{aligned}
& \text { Anfwer to Dr. Robinson. } \\
& \text { "C Black Notley, April 1, 1684. }
\end{aligned}
$$

" Yours of the Ioth inftant I received, and therein an enclofed specimen of the Canada fugar, a thing to ne ftrange and before muheard of. It were well worth the experiment you mention. I therefore engaged a friend and neighbour of mine, an ingenious apothecary, whom I employed yefterday to boil the juice of the greater maple, a tree which grows freely half a mile off from my refidence. Having made an extract, he found a whitifh fubftance, like to brown fugar, and tafting very fweet, immerfed in a fubftance of the colour and confiftency of moloffes. Upon curing, I have no doubt it will make perfect fugar. When it is cured, I will give you a further account of it." 
Here the matter ended; and after the paper given you on the American maple (fee p. 182), I hope the fubject will be again purfued with ardour in this country, and this curious inveftigation turn of profit to this nation.-I hall fend you, for your next number, a paper on the mulberry-tree, and the rearing of filk-worms.

\section{NTELLIG E N C E.}

\section{LEARNED SOCIETIES.}

\section{DENMARK.}

THE Royal Society of Copenhagen has this year propofed a gold medal, value 100 rix-dollars, for the beft anfwer to each of the following queftions :

I. HISTORY.

Quænam gentes ante Norvægicos Americam invenerint, et itinera per mare in hanc terræ regionem inftiterint? Quoufque detecta Norvægicorum in America præfertim Auftrum verfus extenfa fuerint? Quæ hac de re conftitui poterunt, argumentis et conjecturis ex foriptis, monumentifve, v.c. munimentis, ædificiis, linguis, traditionibus Americanis probanda funt.

"What nations difcovered America, and kept up an in" tercourfe by fea with that country before the Norwegians? "How far diul the difcoveries of the Norwegians in America " extend towards the South? The proofs and grounds of "s conjecture mult be drawn partly from written documents "and partly from monuments, fuch as fortifications, coli"fices, languages and traditions fill exifting in America."

II. IN THE MATHCMATICS.

Invenire funstionem omnium quantitatum qua conjunstim determinant magnitudinem effectus calorifici, cujufcunque materiei igni accipiendo aptæ in re familiari ufitatz, tam ligni, quam cefpitis caminarii et lithantracis, feu carbonum foffilium cujafcunque fpecici. 